\title{
Why is it important to correctly identify Haemonchus species?
}

\author{
Por que é importante a identificação correta das espécies de Haemonchus?
}

\author{
Alessandro Francisco Talamini do Amarante ${ }^{1 *}$
}

${ }^{1}$ Instituto de Biociências, Departamento de Parasitologia, Universidade Estadual Paulista - UNESP

Received August 17, 2011

Accepted November 17, 2011

\begin{abstract}
Parasitic gastroenteritis caused by Haemonchus spp. is a major cause of economic losses in the livestock industry because it impairs weight gain and increases mortality in cattle and small ruminants, especially in tropical and subtropical areas. The proper identification of the various species, as well as knowledge regarding the epidemiology of parasitic gastroenteritis, is essential for the establishment of sustainable strategies of parasite control. This review focuses on the use of easily applied, low-cost parasitological methods of identifying Haemonchus species on the basis of their morphology. In most studies carried out in Brazil, the distinctions between Haemonchus contortus and Haemonchus placei have not been considered. Many reports of $H$. contortus, particularly in cattle, might actually represent $H$. placei. The appropriate identification of species is therefore indispensable. In addition to the measurement of male spicules, new morphological characteristics, such as the synlophe, should be evaluated in order to differentiate between and among species. Measurements of infective larvae in fecal cultures can also indicate the identity of Haemonchus species. This approach can be quite useful in studies that do not involve animal sacrifice, such as studies of anthelmintic resistance based on the fecal egg count reduction test.
\end{abstract}

Keywords: Haemonchus placei, Haemonchus contortus, Haemonchus similis, ruminants, morphology.

\section{Resumo}

Infecçôes por Haemonchus spp. são uma das principais causas de perda econômica nas criaçôes de ruminantes devido à redução no ganho de peso e mortalidade de bovinos e pequenos ruminantes, especialmente em regióes com clima tropical e subtropical. A identificação precisa das diferentes espécies, bem como o conhecimento sobre a epidemiologia das gastroenterites parasitárias, são fundamentais para a elaboração de estratégias sustentáveis de profilaxia das parasitoses. Essa revisão tem por objetivo central, abordar os principais métodos parasitológicos utilizados na identificação morfológica das espécies, os quais se caracterizam pela facilidade e baixo custo. Na maioria dos estudos realizados no Brasil, a distinção entre as espécies Haemonchus contortus e Haemonchus placei não tem sido considerada. Vários relatos de $H$. contortus, particularmente em bovinos, podem se tratar na verdade da infecção dos animais por $H$. placei. A identificação correta das espécies é, portanto, fundamental. Além das medidas dos espículos dos exemplares machos, outros detalhes morfológicos, tais como a sínlofe, devem ser avaliados com o objetivo de auxiliar na diferenciação das espécies. Mensuraçôes das larvas infectantes, obtidas em coproculturas, podem também indicar a espécie de Haemonchus presente. Esse procedimento pode ser útil especialmente em estudos que não envolvem a necropsia de animais, como é o caso de testes destinados a avaliar a resistência anti-helmíntica em rebanhos.

Palavras-chave: Haemonchus placei, Haemonchus contortus, Haemonchus similis, ruminantes, morfologia.

\section{Introduction}

Parasitic gastroenteritis caused by Haemonchus spp. is a major cause of economic losses in the livestock industry because it impairs weight gain and increases mortality in cattle and small ruminants, especially in tropical and subtropical areas. The prophylaxis of parasitic gastroenteritis relies heavily on anthelmintic treatments. However, their frequent use has led to the appearance of resistant

\footnotetext{
${ }^{*}$ Corresponding author: Alessandro Francisco Talamini do Amarante Departamento de Parasitologia , Instituto de Biociências - IB, Universidade Estadual Paulista - UNESP,

CEP 18618-970, Botucatu, SP, Brazil

e-mail: amarante@ibb.unesp.br
}

parasite populations, which have been jeopardizing the livestock industry worldwide. There have been many reports of anthelmintic resistance, including resistance to Haemonchus species, in small ruminants (ALMEIDA et al., 2010) and cattle (SUTHERLAND; LEATHWICK, 2011). Therefore, the proper identification of the various species, as well as knowledge regarding the epidemiology of parasitic gastroenteritis, is essential for the establishment of sustainable strategies of parasite control.

Until recently, it was difficult to distinguish between $H$. placei and $H$. contortus, because of their similar morphology. Therefore, many reports of $H$. contortus, particularly in Bovinae, might 
actually represent $H$. placei (HOBERG et al., 2004). This problem is evident in various studies of the epidemiology of Haemonchus infection in ruminants in Brazil. The discrepancies among epidemiological studies in cattle can be observed in Table 1. In most such studies, the distinctions between $H$. contortus and $H$. placei were not considered. Some authors followed the criteria, established by Almeida (1935) and by Gibbons (1979), that do not accept $H$. placei as a valid species, whereas others simply referred to specimens found in small ruminants as $H$. contortus and those found in cattle as $H$. placei. It is known that both species can simultaneously infect cattle and small ruminants specially when there are shared pastures (AMARANTE et al., 1997; ACHI et al., 2003; JACQUIET et al., 1998). In studies of anthelmintic resistance, $H$. placei and $H$. contortus were both identified in cattle raised in Brazil (CONDI et al., 2009) and in the USA (GASBARRE et al., 2009). In the latter experiment, the $H$. contortus encountered were well adapted to transmission in cattle, because the pastures under study had not been grazed by small ruminants for more than 40 years. Although considerable advances have been made toward understanding the genomics of nematode parasites, most cases of haemonchosis occur in the tropics, where modern technology is typically unavailable due to its high costs. Therefore, the use of traditional parasitological methodology continues to be an effective tool in the diagnosis and epidemiological study of parasitic gastroenteritis. This review focuses on the use of easily applied, low-cost parasitological methods of identifying Haemonchus species on the basis of their morphology.

\section{Species of Haemonchus}

One of the first detailed reviews of Haemonchus spp. was published by Almeida (1935). On the basis of the male copulatory structures (bursa and spicules), the author classified
10 Haemonchus species as valid (Table 2). The author did not mention $H$. placei, and the specimens obtained from cattle were designated H. contortus. Later, Gibbons (1979) also established a list of valid Haemonchus spp., comprising nine species. The classification was based on the number and arrangement of the longitudinal cuticular ridges and male characteristics such as dorsal ray, distal ends of spicules, and gubernaculum. The author considered $H$. place $i$ and $H$. contortus it to be synonymous and therefore excluded $H$. place $i$ from the list of valid species (GIBBONS, 1979). However, in a subsequent study, co-authored by Gibbons (HOBERG et al., 2004), H. placei was recognized as a valid species. In that study, the authors performed a phylogenetic analysis of 25 morphological characteristics and established a list of twelve valid Haemonchus species (Table 2). Of those twelve species, three have been reported in ruminants raised in Brazil: $H$. contortus, $H$. similis, and $H$. placei.

\section{Morphological and Cytogenetic Differen- ces Among Species}

Among the parasite species that infect domestic ruminants, male specimens of $H$. similis are easily distinguished, because they present spicules that are shorter than those observed for $H$. placei and $H$. contortus, whereas the distances of the barbs to distal end of the spicules of $H$. similis are longer (Table 3 ).

Although various studies have confirmed the distinctions between $H$. placei and $H$. contortus, there is still some debate regarding their individual identities. In a recently published veterinary parasitology textbook, Taylor et al. (2010, p. 59) stated:

Until recently, the sheep species were called $H$. contortus and the cattle species $H$. placei. However, there is now increasing evidence that these are the single species $H$. contortus with only strain adaptation for cattle and sheep.

Table 1. Prevalence of Haemonchus placei, H. contortus, and H. similis in cattle raised in different regions of Brazil. Means of infection intensity ${ }^{a}$ are in parentheses.

\begin{tabular}{lccccc}
\hline \multicolumn{1}{c}{ Location, state } & $\mathbf{n}$ & $\boldsymbol{H . p l a c e i}$ & H. contortus & H. similis & Reference \\
\cline { 3 - 5 } & & Prevalence (MI) & Prevalence (MI) & Prevalence (MI) & \\
\hline 19 counties in SP, MG, GO, and MT & 38 & - & $7.9 \%(192)$ & $63.2 \%(621)$ & Machado et al. (1979) \\
13 counties in MT and MS & 65 & - & $23.9 \%$ & $76.1 \%$ & Grisi and Nuernberg (1971) \\
Campo Maior, PI & $24^{\mathrm{b}}$ & - & $96 \%(1378)$ & $92 \%(764)$ & Girão et al. (1985) \\
& $24^{\mathrm{c}}$ & - & $84 \%(1304)$ & $96 \%(1139)$ & \\
Itaju do Colônia region, BA & 48 & - & $72.9 \%(493)$ & $81.3 \%(483)$ & Santana et al. (1989) \\
Nhecolandia, MS & 45 & - & $71.1 \%(96)$ & $88.9 \%(1854)$ & Catto and Ueno (1981) \\
Formiga, MG & 76 & $100 \%(3896)$ & - & $29.0 \%(160)$ & Santos et al. (2010) \\
Seropédica, RJ & 98 & $96-100 \%(559-1720)$ & - & - & Pimentel Neto and Fonseca (2002) \\
Jaboticabal, SP & 42 & $97.6 \%(2010)$ & - & $21.4 \%(175)$ & Borges et al. (2001) \\
Irapuá, SP & 40 & - & $12.5 \%(8)$ & $75.0 \%(179)$ & Rodrigues et al. (1985) \\
Ilha Solteira, SP & 6 & - & $83.3 \%(151)$ & $83.3 \%(463)$ & Zocoller et al. (1983) \\
Northwestern, SP & 48 & $33.3 \%$ & - & $33.3 \%$ & Bresciani et al. (2001) \\
Sáo Carlos region, SP & 74 & - & $100 \%(988)$ & $43.2 \%(116)$ & Oliveira and Matsumoto (1985) \\
Santa Maria, RS & 12 & $91.7 \%(631)$ & - & $66.7 \%(374)$ & Santiago et al. (1975) \\
Itaqui, RS & 18 & $83.3 \%(382)$ & - & $16.7 \%(57)$ & Santiago et al. (1975)
\end{tabular}

$\mathrm{n}$ = number of animals; $\mathrm{SP}=$ São Paulo; MG = Minas Gerais; GO = Goiás; MT = Mato Grosso; MS = Mato Grosso do Sul; BA = Bahia; PI = Piauí; RJ = Rio de Janeiro; ${ }^{\mathrm{a}} \mathrm{MI}$ (mean intensity) = Total number of parasites of each species/number of hosts infected with that parasite; ${ }^{\mathrm{b}} \mathrm{g}-12$ months of age; ${ }^{\mathrm{c}} 20-24$ months of age. 
This is inconsistent with other data in the literature. There is considerable morphological, biological, and genetic evidence of the existence of both species. In this context, there are key differential aspects.

\section{Synlophe}

The system of longitudinal surface cuticular ridges, known as synlophe, shows significant differences among species: In both sexes of $H$. contortus, the synlophe extend significantly beyond midbody, whereas they end near midbody in both sexes of H. placei (LICHTENFELS et al., 1986). In addition, the synlophe system of $H$. contortus has 30 ridges in the region of the posterior half of the esophagus, whereas $H$. placei and $H$. similis have 34 (LICHTENFELS et al., 1994).

\section{Spicules and spicule barbs}

Despite occasional anomalies, male characteristics are more reliable and suitable as a means of species identification than are female characteristics. Because numbers of the vulvar flaps and their shapes are variable and dependent on several factors, they cannot be relied upon for specific and generic differentiation (GIBBONS, 1979).

Table 2. Valid Haemonchus species, according to Almeida (1935), Gibbons (1979) and Hoberg et al. (2004).

\begin{tabular}{lll}
\hline \multicolumn{1}{c}{ Almeida (1935) } & \multicolumn{1}{c}{ Gibbons (1979) } & Hoberg et al. (2004) \\
\hline H. contortus & H. contortus & H. contortus \\
H. longistipes & H. longistipes & H. longistipes \\
H. similis & H. similis & H. similis \\
H. lunatus* & & \\
H. bedfordi & H. bedfordi & H. bedfordi \\
H. vegliai & H. vegliai & H. vegliai \\
H. mitchelli & H. mitchelli & H. mitchelli \\
H. bispinosus* & & \\
H. cervinus* & & \\
H. lawrencei & H. lawrencei & H. lawrencei \\
& H. dinniki & H. dinniki \\
& H. krugeri & H. krugeri \\
& & H. horaki \\
& & H. placei \\
& & H. okapiae \\
\hline
\end{tabular}

*Synonymous with $H$. contortus, according to Gibbons (1979).
Male parasites identified as $H$. contortus present spicules and spicule barbs that are smaller than are those of $H$. placei. These differences were consistent in specimens collected in several regions of the world, such as Australia (ROBERTS et al., 1954), North America (HERLICH et al., 1958; LICHTENFELS et al., 1994), South America (SANTIAGO, 1968; AMARANTE et al., 1997) and Africa (JACQUIET et al., 1997; ACHI et al., 2003). Measurements taken by Lichtenfels et al. (1994) from specimens selected from different geographic regions and from several host species are presented in Table 3 and demonstrate consistent differences among Haemonchus species.

In order to identify individual male worms of Haemonchus species, Achi et al. (2003) described a linear discriminate function combining three measures of male spicules:

$$
D F=0.0016 T L+0.128 T H r+0.152 T H L-9.97
$$

where $D F$ is the discriminate function, $T L$ is the total length of the spicule, $T H r$ is the distance from the tip to the barb of the right spicule, and $T H l$ is the distance from the tip to the barb of the left spicule. Species identification was established as follows:

- DF < 0.63: Haemonchus contortus

- $0.63<\mathrm{DF}<3$ : Haemonchus placei

- DF > 4: Haemonchus similis

In conclusion, the measurements of the spicules should be the first method employed to identify Haemonchus species, which easily allows the identification of $H$. similis. Overlap between measurements of $H$. placei and $H$. contortus can occur, casting doubt upon the correct identification. In this case, the enumeration of the longitudinal surface cuticular ridges (synlophe) can help distinguish between $H$. contortus and $H$. placei. The former has 30 ridges in the region of the posterior half of the esophagus, whereas the latter has 34. Synlophe studies rely on the analysis of histological preparations. However, in our laboratory, we demonstrated that, with the use of a sharp needle under a stereomicroscope, it is possible to cut a transverse section of the body at the esophagealintestinal junction, i.e., a slice of Haemonchus, which can be examined under microscopy for enumeration of the cuticular ridges (unpublished data). Lichtenfels et al. (1986) also studied cross-sections of Haemonchus specimens obtained by free-hand cuts with a cataract knife.

\section{Infective larvae}

Infective larvae of $H$. placei are longer and more robust than are those of $H$. contortus (ROBERTS et al., 1954; SANTIAGO 1968), although $H$. similis infective larvae are shorter than either

Table 3. Morphometrics of male specimens of Haemonchus contortus, H. placei, and H. similis. Measurements are ranges followed by means in parentheses.

\begin{tabular}{lccc}
\multicolumn{1}{c}{ Morphological variable } & H. contortus & H.placei & H. similis \\
\hline Body length, in mm, range (mean) & $11.1-17.0(13.1)$ & $10.9-18.9(14.4)$ & $7.3-10.1(8.8)$ \\
Gubernaculum length, in $\mu$ m, range (mean) & $195-255(221)$ & $210-270(245)$ & $142-198(179)$ \\
Spicule length, in $\mu \mathrm{m}$, range (mean) & $383-475(425)$ & $438-511(481)$ & $304-389(341)$ \\
Right spicule barb length*, in $\mu \mathrm{m}$, range (mean) & $37-48(42)$ & $45-60(55)$ & $62-81(71)$ \\
Left spicule barb length*, in $\mu \mathrm{m}$, range (mean) & $19-24(22)$ & $22-32(27)$ & $41-65(54)$ \\
\hline
\end{tabular}

${ }^{*}$ Distances from spicule barbs to distal tips of spicules. Table adapted from Lichtenfels et al. (1994). 
(SANTIAGO, 1968). In a detailed study of the biology and morphology of Haemonchus species, Santiago (1968) measured the infective larvae of Haemonchus and the mean values are presented in Table 4. Therefore, it is possible to have an indication about the identity of Haemonchus species based on the measurements of infective larvae present in fecal cultures. This approach can be very useful in studies that do not involve animal sacrifice, as in those of anthelmintic resistance based on the fecal egg count reduction test.

\section{Chromosome morphology}

The first detailed study of the cytology of ovine and bovine strains of Haemonchus was carried out in Australia by Bremmer (1955). The author observed that all $H$. contortus chromosomes (the autosomes and the X chromosome) presented similar morphology, whereas the $\mathrm{X}$ chromosome of $H$. placei differed from the autosomes in terms of morphology, the X chromosome being larger. Such differences in chromosome morphology were also observed in other studies (LE JAMBRE; ROYAL, 1980; AMARANTE et al., 1997).

In a study involving cross-breeding between $H$. placei and H. contortus, Bremmer (1955) obtained fertile hybrid females, which were also seen, particularly in sheep, in a natural, mixed infestation, when cattle, sheep, or goats grazed the same pasture. These hybrids, however, appeared only in small numbers and were never seen in animals with pure infestations, suggesting that there is some fertility barrier. In Brazil, the identification of Haemonchus species based on the chromosome morphology of specimens matched the identification of the same specimens based on length of spicule barbs (AMARANTE et al., 1997).

In hybridization experiments, Le Jambre (1979) observed that F1 males obtained by mating $H$. contortus males with $H$. placei females were sterile. Female hybrids from these generations had a low level of fertility when backcrossed to males of either parent species. Cytological studies of the hybrid males indicated that sterility was due to various types of meiotic disturbance and that spermatogenesis was arrested during metaphase I. In addition, many hybrid males produced by backcrossing hybrids with parental species had grossly deformed spicules.

\section{Haemonchus Species in Ruminants in Brazil}

In studies involving small ruminants in Brazil, $H$. contortus has been reported to be the major species infecting the abomasums of sheep and goats (Amarante, 2009; Vieira et al., 2009). $H$. placei was observed in sheep only when tracer lambs were placed on pasture grazed simultaneously by sheep and cattle (AMARANTE et al., 1997; ROCHA et al., 2008).

Haemonchus similis is frequently found in cattle in Brazil (Table 1) and has not been detected in sheep, even when they share pastures with $H$. similis-infected cattle (SANTIAGO, 1968; AMARANTE et al., 1997; ROCHA et al., 2008). Likewise, in Martinique (French West Indies), lambs sharing pastures with $H$. similis-infected cattle did not become infected (GIUDICI et al., 1999). In the Ivory Coast, a few specimens of $H$. similis were found in naturally infected sheep that shared
Table 4. Morphometrics of infective larvae of Haemonchus contortus, H. placei, and H. similis.

\begin{tabular}{lcc}
\hline \multicolumn{1}{c}{ Species } & $\begin{array}{c}\text { Total larvae length, } \\
\text { in } \boldsymbol{\mu m}\end{array}$ & $\begin{array}{c}\text { Sheath tail length*, } \\
\text { in } \boldsymbol{\mu \text { m }}\end{array}$ \\
\cline { 2 - 3 } & mean $(\mathbf{S E})$ & mean $(\mathbf{S E})$ \\
\hline H. contortus & $681.7(2.3)$ & $73.6(0.53)$ \\
H. placei & $784.6(2.5)$ & $99.2(0.70)$ \\
H. similis & $611.1(5.4)$ & $57.3(0.8)$ \\
\hline
\end{tabular}

${ }^{*}$ Distance between the tip of the larval tail and the end of the sheath tail. Table adapted from Santiago (1968).

pastures with cattle in the Savannah (ACHI et al., 2003). These findings confirm the high specificity of $H$. similis, which almost exclusively parasitizes cattle. One exception was reported in wild ruminants in Brazil. In six species of deer (Cervidae) in the states of Mato Grosso do Sul and São Paulo, the prevalence of H. similis infection was found to be $45.2 \%$ (NASCIMENTO et al., 2000). In that same study, the reported prevalence of $H$. contortus infection was $76.2 \%$. It is of note that those authors did not attempt to differentiate between $H$. placei and $H$. contortus. Therefore, it is possible that the parasites identified as $H$. contortus in deer were in fact $H$. placei, because of the identification problems previously mentioned.

H. similis was reported as the dominant species in the abomasums of cattle raised in locations with high annual mean temperatures $\left(>23^{\circ} \mathrm{C}\right)$. In Brazil, various studies have been conducted in such locations, including the states of Mato Grosso and Mato Grosso do Sul (GRISI; NUERNBERG, 1971; CATTO; UENO, 1981), as well as the cities of Tupi Paulista, in the state of Sáo Paulo (ROCHA et al., 2008), and Governador Valadares, in the state of Minas Gerais (LIMA, 1998). In certain areas of the states of São Paulo (BORGES et al., 2001), Minas Gerais (SANTOS et al., 2010), Paraná (BRICARELLO et al., 2007), and Rio Grande do Sul (SANTIAGO et al., 1975), where the annual mean temperatures are lower, $H$. similis is also found, but $H$. place $i$ is the predominant species (Table 1).

Studies carried out in Brazil routinely demonstrate the presence of $H$. similis in cattle. One exception was an experiment conducted in the state of Rio de Janeiro and involving dairy cattle, in which the authors found only $H$. placei, with high worm burdens, especially from April to September (PIMENTEL NETO, 1976).

\section{Final Remarks}

For most Brazilian states, there are no consistent epidemiological data related to haemonchosis in ruminants. Given the enormous economic importance of the disease to the Brazilian livestock industry, this is an unacceptable situation. The problem is aggravated by the absence of standardized methodology to differentiate between $H$. contortus and $H$. placei. Therefore, the appropriate identification of species is indispensable. In addition to the measurement of male spicules, new morphological characteristics, such as the synlophe, should be included for differentiation between species. In addition, molecular markers can be developed to identify the species based on DNA extracted from eggs or from third stage 
larvae obtained from cultures. If possible, the parasite collections evaluated in previous studies should also be reanalyzed with these new approaches in order to clarify this issue.

\section{References}

ACHI, Y. L. et al. Host specificity of Haemonchus spp. for domestic ruminants in the savanna in northern Ivory Coast. Veterinary Parasitology, v. 116, n. 2, p. 151-158, 2003. http://dx.doi.org/10.1016/ S0304-4017(03)00258-9

ALMEIDA, F. A. et al. Multiple resistance to anthelmintics by Haemonchus contortus and Trichostrongylus colubriformis in sheep in Brazil. Parasitology International, v. 59, n. 4, p. 622-625, 2010. PMid:20887800. http://dx.doi.org/10.1016/j.parint.2010.09.006

ALMEIDA, J. L. Revisão do gênero Haemonchus Cobb, 1898: (Nematoda: Trichostrongylidae). Memórias do Instituto Oswaldo Cruz, v. 30, n. 1, p. 57-114, 1935. http://dx.doi.org/10.1590/S007402761935000700002

AMARANTE, A. F. T. Nematoides gastrintestinais em ovinos. In: CAVALCANTE, A. C. R. et al. (Eds.). Doenças parasitárias de caprinos e ovinos: epidemiologia e controle. Brasília: Embrapa Informação Tecnológica, 2009. p. 19-61.

AMARANTE, A. F. T. et al. Host specificity of sheep and cattle nematodes in São Paulo state, Brazil. Veterinary Parasitology, v. 73, n. 1-2, p. 89-104, 1997. http://dx.doi.org/10.1016/S0304-4017(97)00036-8

BORGES, F. A. et al. Fauna helmintológica de bovinos da regiáo de Jaboticabal, Estado de São Paulo, Brasil. Semina: Ciências Agrárias, v. 22 , n. 1, p. 49-53, 2001.

BREMMER, K. C. Cytological studies on the specific distinctness of the ovine and bovine "strains" of the nematode Haemonchus contortus (Rudolphi) Cobb (Nematoda: Trichostrongylidae). Australian Journal of Zoology, v. 3, n. 3, p. 312-323, 1955.

BRESCIANI, K. D. S. et al. Freqüência e intensidade parasitária de helmintos gastrintestinais em bovinos abatidos em frigorífico da região noroeste do Estado de São Paulo, SP, Brasil. Semina: Ciências Agrárias, v. 22, n. 1, p. 93-97, 2001.

BRICARELLO, P. A. et al. Field study on nematode resistance in Nelorebreed cattle. Veterinary Parasitology, v. 148, n. 3-4, p. 272-278, 2007. PMid:17659839. http://dx.doi.org/10.1016/j.vetpar.2007.06.013

CONDI, G. K.; SOUTEllo, R. G. V.; AMARANTE, A. F. T. Moxidectin-resistant nematodes in cattle in Brazil. Veterinary Parasitology, v. 161, n. 3-4, p. 213-217, 2009. PMid:19251366. http://dx.doi.org/10.1016/j.vetpar.2009.01.031

CATTO, J. B.; UENO, H. Nematodioses gastrintestinais em bezerros zebus no pantanal matogrossense. I - Prevalência, intensidade de infecção e variação estacional. Pesquisa Agropecuária Brasileira, v. 16, n. 1, p. 129-140, 1981.

GASBARRE, L. C. et al. The identification of cattle nematode parasites resistant to multiple classes of anthelmintics in a commercial cattle population in the US. Veterinary Parasitology, v. 166, n. 3-4, p. 281-285, 2009. http://dx.doi.org/10.1016/j.vetpar.2009.08.018

GIBBONS, L. M. Revision of the genus Haemonchus Cobb, 1898: (Nematoda: Trichostrongylidae). Systematic Parasitology, v. 1, n. 1, p. 3-24, 1979. http://dx.doi.org/10.1007/BF00009771
GIRÃO, E. S.; GIRÃO, R. N.; MEDEIROS, L. P. Prevalência, intensidade de infecção e variação estacional de helmintos em bovinos no Estado de Piauí. Pesquisa Agropecuária Brasileira, v. 20, n. 8, p. 889-897, 1985.

GIUDICI, C. et al. Changes in gastro-intestinal helminth species diversity in lambs under mixed grazing on irrigated pastures in the tropics (French West Indies). Veterinary Research, v. 30, n. 6, p. 573-581, 1999.

GRISI, L.; NUERNBERG, S. Incidência de nematódeos gastrointestinais de bovinos, no Estado de Mato Grosso. Pesquisa Agropecuária Brasileira, Série Veterinária, v. 6, p. 145-149, 1971.

HERLICH, H.; PORTER, D. A.; KNIGHT, R. A. A study of Haemonchus in cattle and sheep. American Journal of Veterinary Research, v. 19, p. 866-872, 1958.

HOBERG, E. P.; LICHTENFELS, J. R.; GIBBONS, L. Phylogeny for species of Haemonchus (Nematoda: Trichostrongyloidea): considerations of their evolutionary history and global biogeography among Camelidae and Pecora (Artiodactyla). Journal of Parasitology, v. 90, n. 5, p. 1085-1102, 2004. PMid:15562609. http://dx.doi.org/10.1645/ GE-3309

JACQUIET, P. et al. Identification of Haemonchus species in domestic ruminants based on morphometrics of spicules. Parasitology Research, v. 83, n. 1, p. 82-86, 1997. http://dx.doi.org/10.1007/s004360050213

JACQUIET, P. et al. Host range and the maintenance of Haemonchus spp. in an adverse arid climate. International Journal for Parasitology, v. 28 , n. 2, p.253-261, 1998. http://dx.doi.org/10.1016/S00207519(97)00185-9

LE JAMBRE, L. F. Hybridization studies of Haemonchus contortus (Rudolphi, 1803) and H. placei (Place, 1893) (Nematoda: Trichostrongylidae). International Journal for Parasitology, v. 9, n. 5, p. 455-463, 1979. http://dx.doi.org/10.1016/0020-7519(79)90049-3

LE JAMBRE, L. F.; ROYAL, W. M. Meiotic abnormalities in backcross lines of hybrid Haemonchus. International Journal for Parasitology, v. 10, n. 4, p. 281-286, 1980. http://dx.doi.org/10.1016/00207519(80)90008-9

LiCHTENFElS, J. R.; PILITT, P. A.; HOBERG, E. P. New morphological characters for identifying individual specimens of Haemonchus spp. (Nematoda: Trichostrongyloidea) and a key to species in ruminants of North America. Journal of Parasitology, v. 80, n. 1, p. 107-119, 1994. PMid:8308643. http://dx.doi.org/10.2307/3283353

LICHTENFELS, J. R.; PILITT, P. A.; LE JAMBRE, L. F. Cuticular ridge patterns of Haemonchus contortus and Haemonchus placei (Nematoda: Trichostrongyloidea). Proceedings of the Helminthological Society of Washington, v. 53, n. 1, p. 94-101, 1986.

LIMA, W. S. Seasonal infection pattern of gastrointestinal nematodes of beef cattle in Minas Gerais State - Brazil. Veterinary Parasitology, v.74, n. 2-4, p. 203-214, 1998. http://dx.doi.org/10.1016/S03044017(97)00164-7

MACHADO, R. Z. et al. Frequência e intensidade de infecção por helmintos gastrintestinais em bovinos abatidos no frigorífico Anglo S/A, Barretos, Estado de São Paulo, Brasil. Científica, número especial, p. 103-109, 1979.

NASCIMENTO, A. A. et al. Infecçôes naturais em cervídeos (Mammalia: Cervidae) procedentes dos Estados do Mato Grosso do Sul e São Paulo, por nematódeos Trichostrongyloidea Cram, 1927. Brazilian Journal of Veterinary Research and Animal Science, v. 37, n. 2, p. 153-158, 2000. Disponível em: <http://www.scielo.br/scielo. 
php?script=sci_arttext $\&$ pid=S1413-95962000000200012\&lng=en $\&$ nrm=iso>. Acesso em: 2 jun. 2011. http://dx.doi.org/10.1590/S141395962000000200012

OLIVEIRA, G. P.; MATSUMOTO, T. Prevalência e intensidade de infecçáo por helmintos em bovinos da bacia leiteira de São Carlos, São Paulo. Pesquisa Agropecuária Brasileira, v. 20, n. 12, p. $1415-1418,1985$.

PIMENTEL NETO, M. Epizootiologia da haemoncose em bezerros de gado de leite no Estado do Rio de Janeiro. Pesquisa Agropecuária Brasileira, Série Veterinária, v. 11, p. 101-114, 1976.

PIMENTEL NETO, M.; FONSECA, A. H. Epidemiologia das helmintoses pulmonares e gastrintestinais de bezerros em região de baixada do Estado do Rio de Janeiro. Pesquisa Agropecuária Brasileira, v. 22, n. 4, p. 148-152, 2002.

ROBERTS, F. H. S.; TURNER, H. N.; McKEVETT, M. On the specific distinctness of the ovine and bovine "strains" of Haemonchus contortus (Rudolphi) Cobb (Nematoda: Trichostrongylidae). Australian Journal of Zoology, v. 2, n. 2, p. 275-295, 1954. http://dx.doi.org/10.1071/ ZO9540275

ROCHA, R. A. et al. Sheep and cattle grazing alternately: Nematode parasitism and pasture decontamination. Small Ruminant Research, v. 75 , n. 2-3, p. 135-143, 2008. http://dx.doi.org/10.1016/j. smallrumres.2007.09.001

RODRIGUES, J.; MACHADO, R. Z.; REIS, V. E. A. Freqüência e intensidade parasitária de helmintos gastrintestinais em bovinos abatidos no matadouro municipal de Irapuâ, SP, Brasil. Arquivo Brasileiro de Medicina Veterinária e Zootecnia, v. 37, n. 3, p. 257-263, 1985.

SANTANA, J. C. R. et al. Ocorrência e variação estacional de helmintos parasitos de bovinos na regiáo de Itaju do Colônia. Agrossistema pastoral de Itapetinga. Pesquisa Agropecuária Brasileira, v. 24, n. 10, p. $1235-1240,1989$.

SANTIAGO, M. A. M. Haemonchus Cobb, 1898 (Nematoda: Trichostrongylidae). Contribuiçáo ao estudo da morfologia, biologia e distribuiçáo geográfica das espécies parasitas de ovinos e bovinos no Rio Grande do Sul. 1968. 89 f. Tese (Livre-Docência)-Universidade Federal de Santa Maria, Santa Maria.

SANTIAGO, M. A. M.; COSTA, U. C.; BENEVENGA, S. F. Estudo comparativo da prevalência de helmintos em ovinos e bovinos criados na mesma pastagem. Pesquisa Agropecuária Brasileira, Série Veterinária, v. 10, p. $51-58,1975$.

SANTOS, T. R. et al. Helminth fauna of bovines from the Central-Western region, Minas Gerais State, Brazil. Ciência Rural, v. 40, n. 4, p. 934-938, 2010. http://dx.doi.org/10.1590/S0103-84782010005000040

SUTHERLAND, I. A.; LEATHWICK, D. M. Anthelmintic resistance in nematode parasites of cattle: a global issue? Trends in Parasitology, v. 27, n. 4, p. 176-181, 2011. PMid:21168366. http://dx.doi.org/10.1016/j. pt.2010.11.008

TAYLOR, M. A.; COOP, R. L.; WALL, R. L. Parasitologia Veterinária. 3. ed. Rio de Janeiro: Guanabara Koogan, 2010. 768 p.

VIEIRA, L. S.; CHAGAS, A. C. S.; MOLENTO, M. B. Nematoides gastrintestinais e pulmonares de caprinos. In: CAVALCANTE, A. C. R. et al. (Eds.). Doenças Parasitárias de caprinos e ovinos: epidemiologia e controle. Brasília: Embrapa Informaçáo Tecnológica, 2009. p. 65-94.

ZOCOLLER, M. C. et al. Infecção natural por helmintos gastrintestinais em bovinos durante os primeiros dois anos de vida, na regiáo de Ilha Solteira, SP. Arquivo Brasileiro de Medicina Veterinária e Zootecnia, v. 35, n. 6, p. 823-825, 1983. 